\title{
Pendidikan Keberagamaan Berbasis Budaya Spiritual Di Kalangan Sai Study Group (SSG)
}

\author{
I Made Wirahadi Kusuma ${ }^{1}$, I Made Pasek Subawa ${ }^{2}$ \\ ${ }^{12}$ Universitas Hindu Negeri I Gusti Bagus Sugriwa Denpasar \\ ${ }^{1}$ wirahadikusuma200030@gmail.com , ${ }^{2}$ imadepaseksubawa@gmail.com
}

\begin{abstract}
Education is not only teaching that emphasizes on cognitive aspects, mastery of academic subjects, and not the development of the character of students towards the environmental reality which is religiously pluralistic. Therefore, although many educational institutions teach about the differences and respect for pluralism and comparative religion, it only comes to a cognitive understanding of each religion and does not know how to behave outside the religious discipline. It has big impact on humanitarian crises, not only at a concrete level in the form of physical culture, but also in non-physical forms which related to changes in attitudes, behavior and values of life. The presence of the Sai Study Group Denpasar (SSGD) religious study group gave a new model to the pattern of religious education amidst the polarization of the development of religious study groups in Bali, especially in the formation of intellectual and character building. Religious education at SSGD contains acts of cognition, not just transfer of knowledge, verbalism, and education banking.
\end{abstract}

Keywords: Education; Religiosity; Spiritual Culture; The Teachings Of Sai

\begin{abstract}
Abstrak
Pendidikan tidak saja sekedar pengajaran yang menonjolkan adalah aspek kognitif, penguasaan subjek akademik, dan bukan pengembangan watak anak didik terhadap realitas lingkungan yang secara keagamaan bersifat pluralistik. Karenanya meskipun banyak lembaga pendidikan yang mengajarkan tentang perbedaan dan penghargaan terhadap pluralisme serta ilmu perbandingan agama, hal itu hanya sampai pada pemahaman kognitif atas masing-masing agama dan tidak tahu bagaimana bersikap di luar disiplin agama itu. Hal tersebut dapat memberikan dampak yang luas terhadap krisis kemanusiaan yang bukan hanya dalam tataran yang konkrit dalam wujud budaya phisik, namun juga dalam wujud non phisik berkaitan dengan perubahan sikap, prilaku dan nilai-nilai kehidupan. Kehadiran kelompok studi kegamaaan Sai Studi Group Denpasar (SSGD) memberikan warna baru terhadap pola pendidikan keberagamaan di tengah polarisasi perkembangan kelompok studi keagamaan di Bali terutama dalam pembentukan intelectual building dan caracter building. Pendidikan keberagamaan di SSGD berisi laku-laku pemahaman (acts of cognition), bukannya sekedar transfer of knowledge, verbalisme, dan banking education.
\end{abstract}

Kata Kunci : Pendidikan; Keberagamaan; Budaya Spiritual; Ajaran Sai 


\section{Pendahuluan}

Pendidikan pada dasarnya tidak bisa lepas dari konteks sosial budaya masyarakatnya. Artinya, pendidikan dalam upaya membentuk prilaku, menanamkan pengetahuan, proses berpikir, nilai-nilai, cara belajar, ketrampilan sosial, serta nilai-nilai kebenaran akan ditentukan juga oleh bagaimana pandangan masyarakatnya tentang dunia dan nilai-nilainya. Lebih jauh dapat pula dikatakan bahwa manfaat relatif dari tujuan-tujuan dan cara pendidikan tertentu adalah berakar pada konteks sosial, budaya, politik, ekonomi dimana orang-orang belajar dan dimana institusi pendidikan itu berfungsi. Dengan demikian, tidaklah ada bagian dari pendidikan termasuk juga proses, isi, dan produknya yang bebas dari pengaruh sosial budaya masyarakat (Sukadi, 2006:1).

Keberadaan Sai Study Group (SSG) Denpasar, melalui pendidikan keberagamaannya mendorong manusia dalam meningkatkan toleransi atau kepekaan sosial terhadap kemiskinan, ketertinggalan, humanisme, penindasan manusia dan lain-lain. Hal ini sejalan dengan idealisme pendidikan Paulo Freire (2002:12-13), bahwa pendidikan sebagai upaya untuk mengembalikan fungsi manusia menjadi manusia agar terhindar dari berbagai bentuk penindasan, kebodohan sampai kepada ketertinggalan. Oleh karena manusia sebagai pusat pendidikan, maka manusia harus menjadikan pendidikan sebagai alat pembebasan untuk mengantarkan manusia menjadi mahluk yang bermartabat dan menghargai perbedaan dalam berbagai dimensinya. SSG memberikan warna baru terhadap pendidikan keberagamaan berbasis budaya spiritual, sebagaimana terlihat dalam simbol "Sarwa Dharma" yang diusung SSG dengan memperlihatkan adanya berbagai simbol agama-agama besar dunia yang disatukan ke dalam suatu lingkaran bunga padma.

Penggunaan simbol Sarwa Dharma tersebut amat menjanjikan bagi pengembangan model pendidikan keberagamaan yang berbasis budaya spiritual, dan membangun semangat dialogis antara berbagai pemeluk agama yang berbeda dalam suatu kelompok studi. Namun demikian, realisasi untuk mempertemukan berbagai kelompok agama yang berbeda ke dalam suatu kelompok belajar yang dipayungi oleh tradisi agama tertentu, pada tataran emperis seringkali tidak sejalan antara teori dengan praktek dan antara harapan dengan kenyataan yang dihadapi dalam kehidupan beragama khususnya dalam mengkonstruksi pemikiran belajar dan pendidikan keberagamaan.

\section{Metode Penelitian}

Metode yang digunakan dalam kajian ini adalah metode kualiatif, dimana sumber datanya adalah hasil wawancara para tokoh-tokoh SSG dan para Bhakta Say yang tersebar pada kelompok-kelompok belajar. Selain menggunakan data wawancara, sumber data lain yang digunakan sebagai pendukung analisis adalah pustaka-pustaka ilmiah yang mengkaji sistem pendidikan keberagamaan yang menggunakan pendekatan budaya spiritual.

\section{Hasil dan Pembahasan}

\section{Teknik Pendidikan Keberagamaan Sai Study Group}

Ada lima teknik atau metode mengajar yang diterapkan dalam pembelajaran agama Hindu dalam program EHP. Kelima tehnik mengajar yang digunakan dalam program Satya Sai yang bersifat unik, sebagaimana ulasan berikut ini. 


\section{a. Doa}

Doa merupakan suatu permohonan langsung kepada Tuhan untuk memimpin dan memberkati kita dalam usaha mengembangkan kelima nilai-nilai kemanusiaan ini, Setiap orang harus berdoa sesuai agama atau kepercayaan masing-masing, Berdoa lebih dahulu juga akan mendorong kepercayaan kepada Tuhan dan keyakinan, bahwa Tuhan selalu hadir untuk menuntun dan menjaga kita.

\section{b. Duduk diam}

Duduk diam merupakan suatu jalan untuk mengembangkan yang diperlukan dalam pikiran untuk dapat berkonsentrasi penuh pada pelajaran. Duduk diam harus menjadi kebiasaan yang mempunyai kekuatan untuk menenangkan badan dan pikiran. Dengan demikian manfaat dan efisiensi maksimal akan tercapai dalam waktu seminimal mungkin.

\section{c. Nyanyian berkelompok}

Lagu-lagu yang diciptakan untuk nyanyian berkelompok harus mencerminkan salah satu dari lima nilai kemenusiaan. Nyanyian berkelompok menciptakan suasana yang gembira dan relaks dengan themanya tentang salah satu dari lima nilai-nilai kemanusiaan, maka lagu ini mendorong untuk menyerap arti nilai yang terkandung dan meninggalkan suatu kesan yang tidak hilang dalam alam pikiran sadar dan alam pikiran di bawah sadar.

Harus diusahakan untuk menciptakan lagu-lagu pujian kepada Tuhan yang dapat diterima oleh semua agama dan kepercayaan. Jika nyanyian pujian dapat dipergunakan dalam nyanyian berkelompok, maka mereka akan mempengaruhi anak-anak (dan orang lain) untuk berpaling ke arah Tuhan. Dengan demikian suasana yang tepat telah tercipta untuk kemajuan lebih jauh dengan menganalisa arti lebih dalam dari nyanyian-nyanyian tersebut.

\section{d. Menceritakan kisah-kisah}

Menceritakan kisah-kisah bermoral akan mengispirasikan anak-anak (dan orang lain) untuk mengembangkan sifat yang baik dan merupakan metode utama untuk menanamkan nilai-nilai ini pada anak-anak. Kisah-kisah ini, jika dikarang, dipilih, diceritakan dan dianalisa dengan baik, akan sangat efektif dengan anakanak yang pada dasarnya masih murni. Kisah-kisah boleh bervariasi dari satu negara ke negara lain, sesuai dengan kebudayaan masing-masing dan harus menyangkut jenis-jenis yang terkait kisah-kisah beriman dan bersejarah, kisahkisah khayalan bermoral, dan kisah-kisah kehidupan para penyayang sesama manusia (humanitarians). Sang guru harus dapat membawa intisari kisah itu dengan modulasi suaranya, gerakan tangannya, ekspresi mukanya; pokoknya segala metode dapat digunakan untuk menarik perhatian para pendengar, Si anak harus dapat menangkap arti lebih dalam dari kisah itu dengan akal-budinya, penilaian dan kesimpulannya sendiri. Jika si anak belum sanggup melakukan, maka harus didorong perlahan-lahan untuk mengembangkan kemampuan ini.

\section{e. Kegiatan-kegiatan Berkelompok}

1) Pekerjaan kesenian (karya) yang ada hubungan dengan nilai-nilai moral yang terkandung dalam kisah-kisah dan pelajaran (sangat cocok untuk kelompok umur 6-9). Ini masih merupakan kegiatan-kegiatan yang dilakukan secara perseorangan.

2) Proyek-proyek atau kegiatan-kegiatan yang dilakukan secara berkelompok dengan tujuan mengembangkansuatu kesadaran kebersamaan (perasaan merupakan suatu persatuan). Ini sangat cocok untuk anak-anak kelompok umur 10-12. 
3) Berdiskusi penting dan kritis untuk kelompok umur 13-15, karena pada umur ini anak-anak perlu mengutarakan perasaan mereka dan ingin membagi perasaan dengan orang lain, yang maksudnya mencari orang dengan pandangan yang sama. Berdiskusi pada kelompok umur 6-9 dan 1012 terutama di gunakan untuk membuat anak-anak mengerti dan menganalisa kisah-kisah yang bermacam-macam (Tiong, 2000:37).

Penerapan Pendidikan Nilai Kemanusiaan dalam lembaga pendidikan formal di SSG khususnya di TK. Sai Prema Kumara, dan SD Satya Sai sebagaimana William F.O'neil (2003:48) mengemukakan bahwa...."semua praktek merupakan praktik dari teori tertentu. Kebanyakan praktik sama sekali tidak didasarkan pada teori apa pun juga. Kebanyakan orang mempraktikkan praktik dan bukan mempraktikkan teori. Pada umumnya orang berperilaku berdasarkan kebiasaan, tatacara, atau dorongan hati (impuls), bukannya dengan melandaskan perilaku pada keyakinan-keyakinan intelektual yang serius. Pendapat O'neil benar karena di dalam penerapan Pengajaran Pendidikan NilaiNilai Kemanusiaan bukanlah diajarkan apa yang tidak dialaminya. Pengajaran Pendidikan Nilai-Nilai Kemanusiaan selalu bertumpu serta memulai dengan apa yang diketahui dan dialaminya, bukan apa yang tidak pernah diketahui dan tidak pernah dialaminya.

Pendidikan TK Prema Kumara dan SD Satya Sai yang dikembangkan di Sai Study Gorup juga memberlakukan hal yang sama. Pada anak-anak TK Sai Prema Kumara dan SD Satya Sai yang baru tiba di halaman sekolah, maka guruguru TK akan menyapa dan menyalaminya dengan kalimat "Selamat Pagi! dengan menyebutkan nama anak tersebut dengan menyalami dan menyapanya. Hubungan yang dialogis ini menunjukkan kedekatan emosional antara guru-murid sebagai bentuk pengamalan pilar kedua, yaitu Kebenaran (Dharma). Anak-anak juga diberlakukan sebagai sahabat yang baik untuk diajak bersapa, bertutur dan berperilaku yang benar. Sebagai respond dari sapaan guru kepada murid menyebabkan anak juga menjawabnya dengan penuh hormat, dan mencium tangan bahkan mencium pipi gurunya ketika disapa di gerbang pintu sekolah.

Dengan demikian guru telah memberikan kontribusi dengan praktik dan contoh-contoh yang konkrit tanpa harus banyak berteori. Guru telah menamamkan kepada murid pola-pola pendidikan nilai-nilai kemanusiaan secara tidak langsung bahwa sapaan, teguran, elusan dan bersalaman adalah wujud konkrit atas terintegrasinya nilai-nilai kemanusiaan yang diajarkan. Pola pendidikan demikian akan memperkecil ketakutan murid kepada gurunya. Kurt Singer (1987:132) sendiri menyatakan bahwa sikap guru yang penuh dengan harapan akan memberikan dampak kepada kemampuan intelek murid-murid.

Saling mengenal secara pribadi akan mengurangi kemungkinan timbulnya tendensi yang agresif. Semakin dekat kita mengenal diri seorang, semakin berat pula rasanya untuk bersikap agresif terhadapnya. Guru yang mempunyai hubungan pribadi dengan murid akan jarang menghadapi agresi jika dibandingkan dengan guru yang bersikap tidak peduli terhadap muridnya (Kurt,1987:154). Memberikan peluang kepada murid semaksimal mungkin untuk melakukan kontak pribadi seperti halnya; murid berkinginan untuk menyapa, bersalaman, atau mengatakan sesuatu adalah indikasi meningkatnya rasa harmonisasi kehidupan proses mengajar baik di dalam kelas maupun di luar. Setidak-tidaknya hubungan pribadi yang tidak dipaksakan antara guru-murid tersebut memungkinkan si murid merubah image guru, kepribadian, simpati dan empati. Cara ini sebagai langkah dini agar dalam proses belajar dan mengajar terdapat hal yang dimengerti. 
Pentingnya komonikasi di dalam praktik sekolah ini bukanlah bertujuan untuk melihat bagaimana pelajaran berjalan atau untuk menyelesaikan pelajaran tersebut selekas-lekasnya, tetapi yang diutamakan adalah penanganan, baik sebagai perorangan maupun di dalam kelompok, serta hubungan antara mahasiswa dengan pembimbing praktek atau latihan kerja mereka. (Kurt,1987: 138).

Hans Zulliger (dalam Kurt,1987: 4) seorang guru dan ahli psikoanalisis dari Swiss mempopulerkan ungkapan "rasa takut membuat orang menjadi bodoh!". Ia menceritakan tentang pengalaman seorang murid perempuan yang seolah-olah bodoh sebagai akibat gangguan pikiran. Hampir beberapa kali murid ini tidak naik kelas, karena dari segi intelektual ia dianggap sebagai murid yang rendah. Gadis ini merasa malu dan merasa takut terhadap sekolah, guru dan teman-temannya. Dengan berjalannya waktu, kali ini murid perempuan ini mendapat guru yang sangat perhatian. Gurunya sangat berhat-hati memberikan kritik yang negatif. Dalam pembicaraan dengan murid tersebut, Guru ini menonjolkan prestasi murid tersebut dan berusaha menemukan kelemahankelemahan si murid tanpa merendahkan murid tersebut. Dalam mengejar ketertinggalan si murid ia tidak berusaha membiarkannya terisolasi sebagai "murid yang bodoh". Guru berusaha melakukan kontak secara pribadi dan hasilnya hanya dalam setahun si murid perempuan yang inteleknya dianggap rendah mampu menjadi murid yang terbaik di dalam kelasnya.

Rasa takut yang ditanam oleh guru, lingkungan teman-temannya akan menjadikannya sebagai penghambat kemajuan intelektualnya, dan itu tertanam di bawah alam sadar berupa sekat dan jarak antara guru dan murid. Hanya dengan melakukan jalinan emosional akan dapat memgembangkan kemampuan intelektualnya, dalam iklim yang diwarnai dengan ciri-ciri kebersamaan, daya tangkap murid serta daya ingat akan bertambah baik. Penyebab kebodohan hanyalah akibat dihinggapi rasa takut yang berlebihan dari pengalamannya.

Sai Study Group bukanlah sebuah institusi pendidikan formal tetapi sebuah organisasi yang lebih mengedepankan aktivitasnya untuk membawa perubahan kerangka berpikir dan perilaku. Sai Study Group memiliki dua altar pemujaan, yakni Altar Utama, yang menghadap ke Utara, menampung sekitar 600 orang, dan Altar Timur, karena altarnya menghadap Timur di khususkan kepada para bhakta yang orang tuanya kebetulan membawa anak-anak.

Di tempat ini juga, setiap hari Selasa dan Kamis (jadwal Bhajan SSG Denpasar mulai pukul 19.00-21.00) anak-anak mendengar materi-materi Pendidikan Nilai-Nilai Kemanusiaan, yang diberikan oleh Guru-guru Balvikas. Pada umumnya, anak-anak Balvikas yang hadir pada waktu hari Kemis akan lebih banyak ketimbang hari Selasa. Alasannya, orang tua mereka mengajak anakanaknya pada waktu Bhajan hari Kemis, yang diyakini sebagai hari untuk menghormati Guru. Dengan demikian, anak-anak mereka akan turut datang ke tempat Bhajan pada hari Kamis dan sekaligus anak-anak dibawa serta dan akan belajar PNK di Center, yang disiapkan oleh Guru-guru Balvikas/Guru PNK. Walaupun untuk hari Selasa juga dilaksanakan pengajaran PNK, sama dengan hari Kemis. Adapun materi PNK akan diberikan pada waktu itu, di altar Utama akan dilaksanakan jadwal Dharmawacana secara bergiliran yang diberikan oleh Pemdharmawacana yang telah ditetapkan jadwalnya secara pasti. Adapun uruturutan kegiatan Bhajan hari Selasa dan Kemis di Sai Study Group Denpasar, akan dimulai dengan mantra-mantra Sai, yang dikumandangkan lewat kaset kemudian dilanjutkan dengan duduk hening selama kurang lebih 15 menit. Sampai tepat pukul 19.00. Lihat jadwal beriktu ini : 
Tabel 1. Jadwal Bhajan

\begin{tabular}{|l|l|l|}
\hline No. & \multicolumn{1}{|c|}{ M A T E R I } & J A D W A L \\
\hline 01. & Duduk hening/Mendengar Mantra Sai & $18.30-18.45$ \\
\hline 02. & Duduk Hening/Meditasi Cahaya & $18.45-19.00$ \\
\hline 03. & Bhajan (kidung-kidung suci) & $19.00-20.00$ \\
\hline 04. & Dharmawacana/Di Altar Utama & $20.00-20.30$ \\
\hline 05. & Pembagian Tirtha/Vibhuti (abu suci) & $20.00-20.45$ \\
\hline 06. & Pengumuman/Doa Penutup & $20.45-21.00$ \\
\hline
\end{tabular}

Jika diperhatikan dengan seksama maka materi pembelajaran Pendidikan Nilai-Nilai Kemanusiaan memang tidak ada sebagaimana dalam Kurikulum Nasional. Meskipun demikian, semua materi pengajaran tetap memadukan antara Kurikulum Nasional dengan memasukkan kearifan lokal serta pengintegrasian Pendidikan Nilai-Nilai Kemanusiaan pada semua bidang pelajaran yang diajarkan seperti; menari, menggambar, bernyanyi dan bercerita dengan menyisipkan nilainilai kemanusiaan tersebut tanpa harus ke luar dari konsensus yang telah disepakati. Pada TK. Sai Prema Kumara, kegiatan menari, drumband, latihan olah suara dengan musik di atas masuk kegiatan ekstra, dari hari Selasa-Jumat. Sehingga dapat digambarkan bahwa disatu sisi, TK Sai Prema Kumara dan SD Satya Sai menerapkan dengan memasukkan nilai-nilai kemanusiaan tanpa harus ke luar dari kurikulum.

\section{Sistem Pendidikan Keberagamaan}

Sesuai dengan konsep yang dipergunakan dalam penelitian ini, maka yang dipergunakan sebagai "payung " dalam pembahasan sistem keberagamaan adalah pendapat Stark dan Glock dalam Roland Robertson (Ed) (1995 : 24) dengan lima dimensi keagamaannya yakni : keyakinan, praktek, pengalaman, pengetahuan, dan konsekuensi-konsekuensi“.unsur-unsur sistem keberagamaan di atas setidaknya dapat dijadikan dasar pengkajian yang lebih dalam mengenai sistem pendidikan Keberagamaan di kalangan Sai Study Group berikut ini.

\section{a. Aspek Keyakinan Sai Study Group}

Pendidikan keberagamaan pada dasarnya bertujuan memantapkan keyakinan para bhakta dan peserta didik di kalangan SSG terhadap Ida Sanghyang Widhi Wasa dan semua manifestasinya melalui pemujaaan dalam bentuk bhajan (sembahyang). Bhajan yang dilakukan setiap Hari Selasa dan Kamis bertujuan untuk memuliakan nama Tuhan seperti ; Gayatri, Ganesa, Guru, Krishna, Laksmi, Brahma, Wishnu, Siwa, Sambo, Mahadewa dan lain-lain. Pendidikan Sai juga mengintroduksi (memperkenalkan) eksistensi beliau dengan berbagai mukjizatNya) sebagai Sad Guru (Guru Sejati) dan diyakini sebagai Awatar pada Zaman Kali. Kadangkala beliau juga diyakini sebagai perwujudan Siwa setelah Shirdi. Beliau akan mengakhiri misi-Nya pada tahun 2020 dan selanjutnya akan menjelma lagi menjadi seorang wanita dan awatara perwujudan Kasih (Prema). Tanggal Kelahiran dan melalui siapa beliau akan lahir sudah ditetapkan pada saat ini.

Penjelasan yang lebih komprehensif mengenai beliau dapat ditelusuri pendapat Prof. Dr. Wayan Jendra yang diambil dari bukunya Variasi Bahasa Kedudukan dan Peran Bhagawan Sri Sathya Sai Baba Dalam Agama Hindu yang diterbitkan Paramita Surabaya dan makalahnya berjudul Awatara dan Gaya Bahasanya yang disampaikan dalam sebuah diskusi tahun 1991 silam. 
Namun sampai saat ini pertanyaan yang paling sering terdengar adalah : "Apakah Sai Baba memang benar awatara? Adakah bukti-bukti konsep religius theistis yang menunjangnya atau hanya bertumpu pada pengalaman batin yang intuitif magnitis? Atau hanya percaya begitu saja, tanpa disertai argumentasi, percaya hanya ikut-ikutan?". Keyakinan para bhakta Sai adalah Sai Baba merupakan Awatara dan diyakini sebagai manifestasi Tuhan pada zaman kali ini.

Dalam Wana Parwa dinyatakan, pada zaman Kali akan lahir awatara yang bernama Kalki. Lalu mengapa Sai Baba yang disebut awatara? Bukanlah Kalki bukan nama lain Sai Baba? Masalah nama ini yang menyebabkan banyak umat Hindu ragu-ragu tentang kehadiran Sai Baba sebagai awatara. Akan tetapi bila dilihat dan diperhatikan ciri-ciri fisik Kalki dan Sai Baba adalah sama. Sai Baba pernah mengatakan, semua awatara zaman Kali ini disebut Kalki. Masalah nama sebenarnya kurang begitu penting. Yang penting adalah ciri-cirinya (Jendra, 2000 : 19).

Peranan Sai Baba lebih besar daripada missi yang diperankan oleh awatara terdahulu. Rama berperan untuk menegakkan sathyam (kebenaran) dan kebajikan (dharma), Sri Krishna berperan menegakkan dharma dan prema (kasih sayang) serta santih, Buddha mempunyai peran untuk mengakkan karma, sedangkan Bhagawan Sri Sathya Sai Baba menegakkan keempat-empatnya (Jendra, 2000 : 20-21).

\section{b. Praktek Agama Sai Study Group}

Ketaatan dan ritual bagaikan ikan dengan air, meski ada perbedaan penting. Apabila aspek ritual dari komitmen sangat formal dan khas publik, semua agama yang dikenal juga mempunyai perangkat tindakan persembahan dan kontemplasi personal yang relatif spontan, informal, dan khas pribadi. Ketaatan di kalangan penganut Hindu diungkapkan melalui sembahyang pribadi, membaca Lontar dan barangkali menyanyi/mekidung ngayah di pura dan lain-lainnya.

Demikian pula halnya dengan pendidikan keberagamaan dalam SSG memiliki ritual-ritual tertentu seperti Bhajan (sembhyang untuk pemujaan Tuhan Berserta segala manifestasi beliau, upacara pujawali di Pura, melakukan agni hotra dan lain-lain. Dalam pelaksanaan ritus, ada perbedaan sedikit dari segi sesajen yang dipergunakan di SSG, terutama isi sesajen yang tidak boleh memakai daging. Selain itu, semuanya sama seperti halnya dengan banten dalam tradisi Hindu Bali. Setiap bhajan yang dilakukan pada Hari Selasa dan Kamis ada banten yakni canang genten/canangsari. Pada saat hari-hari tertentu di Padmasana, ada banten yang lebih besar, seperti daksina. Tetapi tidak memakai tidak memakai bahan dari daging apapun. Bhajan dilakukan dengan urutan tertentu sesuai tingkat istha dewata yang dipuja, dan hal itu sudah bersifat tradisi dalam persembahyangan.

Mengenai pakaian yang dipergunakan pada saaat bhajan, menurut pengetahuan informan dan bhakta sai menyatakan tidak ada ketentuan khusus. Hanya saja ada anjuran, kalau bisa memakai pakaian yang sopan, berwarna putih. Bisa berpakaian adat, bisa juga tidak. Masalah pakaian, tidak begitu streng asal, sopan.

\section{c. Pengalaman Agama dalam Sai Study Group}

Menjadi seorang bhakta Sai dan penganut ajaran Sai Baba sarat dengan pengalaman religius, bukan saja sejak sebelum menjadi bhakta dan bahkan sejak menjadi bhakta Sai seringkali mengalami banyak pengalaman, dan pengalaman setiap orang berbeda-beda. Ada yang berangkat dari pergulatan bathin karena pada tahap awal sangat meragukan eksistensi Sai Baba, namun kemudian mengalami 
mukjizat yang sangat menakjubkan sehingga yang bersangkutan menjadi bhakta. Ada yang dipanggil karena diselamatkan dari penyakit kronis atau penyakit yang sangat berbahaya dan dapat mengancam nyawanya. Ada pula yang menjadi bhakta karena diberikan bekah rejeki yang melimpah dan dibantu dalam mengatasi persoalan sulit dan lain-lain.

Hal ini juga dinyatakan oleh salah seorang tokoh Sai Baba yang dalam tulisaya dinyatakan bahwa adapun bentuk "panggilan" ada berbagai macam. Misalnya, seseorang yang sakit, kemudian mimpi diobati Baba dan benar-benar sembuh. Ada pula orang menangis penuh haru rindu dan ingin bertemu, begitu usai membaca buku tentang Baba. Ada yang lama merenung dan meditasi, akhirnya muncul Sai Baba di hadapannya. Banyak lagi bentuk panggilan lainnya. (Jendra, $2000: 15$ ).

Umat yang telah (banyak) membaca buku-buku tentang Bhagawan Sri Sathya Sai Baba dan kemudian "terpanggil" dalam berbagai bentuk "panggilan" meyakini bahwa Bhagawan Sri Sathya Sai Baba adalah seorang awatar. Namun umat yang telah banyak membaca pustaka tentang ajaran Baba, belum menjamin bahwa orang tersebut "terpanggil" kalau memang tidak dikehendaki Baba. Ada kalanya orang yang belum banyak membaca, tetapi baru hanya melihat gambarNya saja sudah merasa ada ketukan "panggilan batin" yang menggerakkan intuisinya dan kemudian meyakini bahwa Sai Baba bukan orang biasa, tetapi orang suci yang luar biasa. Kasus semacam ini banyak sekali jika diungkapkan. (Jendra, $2000: 15)$.

Pengalaman keagaam dengan Sai Baba bermacam-macam dan hal itu sesuai dengan tingkat kesucian setiap orang dan juga karma masing-masing. Hal ini juga dapat dipahami mengingat perjalanan hidup dan perjalanan spiritual setiap orang berbeda-beda.

\section{d. Pengetahuan Agama berbasis Program Pendidikan Sai}

Menjadi seorang bhakta yang mantap dalam wawasan isoterik hendaknya mampu menguasai ajaran agama secara komprehensip. Penguasaan ajaran agama yang parsial dan wawasan yang sempit menjadikan seorang bhakta tidak mampu melaksanakan fungsinya dengan baik. Ia akan cenderung tertutup, fanatik sempit, egoistis, bahkan rendah diri atau minder bila berhadapan dengan cendekiawan umat Hindu dan sulit dibayangkan apabila berhadapan dengan cendekiawan atau rohaniwan umat beragama lain yang memang disiapkan sejak dini untuk tugastugas pengkajian agama. Persiapan dini ini berlanjut melalui metoda akademis yang memadai.

Pengetahuan keagamaan yang diajarkan dalam pendidikan keberagamaan bukan hanya pengetahuan duniawi seperti yang diajarkan dalam pendidikan formal (TK dan SD Satya Sai), namun juga pengetahuan yang dapat mengembangkan moralitas dan kesalehan individual dan sosial. Jalan Sai ke Kebahagiaan melalui pengertian dan praktek Spiritualitas, Pelayanan Sosial dan Pendidikan Nilai-nilai Kemanusiaan (Kebenaran, Kebajikan, Kedamaian, Kasih sayang dan Tanpa-kekerasan). Hal terpenting dari pembelajaran agama adalah memberikan petunjuk yang praktis untuk mencapai jalan spiritual bagi para bhakta untuk mendekatkan diri dengan Tuhan.

Pelajaran spiritualitas ibarat peta, yang menunjukkan jalan dari masa kini di alam materi kehidupan ini ke kehidupan alam baka di hadapan Tuhan Yang Maha Esa. Para penziarah yang menempuh jalan ini sangat tertolong, karena dapat memilih dari beberapa peta yang disediakan oleh berbagai agama dan kepercayaan. Semua peta ini menawarkan jalan yang berbeda untuk memenuhi 
selera sang penziarah, sehingga setiap orang dapat menemukan peta perjalanan yang paling cocok dengan dirinya.

Sai Baba telah berkata, bahwa setiap agama memiliki semua jawaban dan semua peta perjalanan yang para bhakta perlukan untuk mencapai Tuhan. Andalah yang harus mengambil keputusan untuk berangkat atau tidak. Hanya para bhakta yang dapat dan harus membuat keputusan. Tuhan hanya menunjukkan jalannya, tetapi para bhakta yang harus menempuh perjalanan itu. Akan tetapi Baba juga mengatakan, bahwa jika para bhakta maju satu langkah di perjalanan ini, maka tujuan itu akan maju sepuluh langkah ke arah bhakta-Nya.

Hal itu tidak terlalu sulit dijelaskan. Karena Baba saat ini berdiam di India, maka dengan sendirinya Baba harus menggunakan bahasa dan istilah setempat. Karena sebab yang sama sebagian pelajaran-pelajaran Beliau terpaksa menggunakan teori-teori yang dibangun atas dasar istilah-istilah dari Veda. Akan tetapi ini tidak berarti, bahwa pelajaran-pelajaran Beliau adalah pelajaran Hindu. Hindu hanya sebutan untuk teori dan ide-ide tertentu. Teori dan ide-ide yang sama mungkin diketemukan pada semua agama lain dengan nama dan sebutan lain.

Segala sesuatu yang berasal dari Tuhan merupakan kebenaran tunggal yang sama. Tidak ada kebenaran yang berbeda-beda. Yang ada hanyalah, nama yang berbeda dalam bahasa yang berbeda untuk kebenaran tunggal yang sama. Seperti segala sesuatu disebut lain dalam bahasa yang berbeda demikian juga nama dan pelajaran Tuhan mempunyai suara dan lambang yang berbeda dalam bahasa yang berbeda. Apapun nama yang para bhakta berikan kepada air, api, tanah, udara dan sebagainya. Akan tetapi nama itu tidak akan mempengaruhi ciri-ciri khasnya. Air tidak mungkin bersifat kering, api tidak mungkin bersifat dingin dan sebagainya. Nilai-nilai kebenaran, kebajikan, kasih-sayang, kedamaian dan tanpa-kekerasan adalah sama dalam semua agama dan kepercayaan. Semua merupakan pelajaran yang berasal dari Tuhan. Ini berarti, bahwa tidak ada dan tidak pernh boleh ada perbedaan misalnya, antara Kasih-sayang Islam, Kasih-sayang Kristen, Kasihsayang Buddhis atau Kasih-sayang Hindu. Kasih-sayang, sebagaimana diajarkan oleh Tuhan, adalah Kasih-sayang, sebagaimana diajarkan oleh Tuhan, adalah kasing-sayang saja, hanya manusia yang mempraktekkan Kasih-sayang ini, kadang-kadang menginterpretasikan serta menggunakannya secara berbeda.

Dengan cara ini para bhakta dapat memanfaatkan pelajaran dan falsafah Sai. Kebenaran yang sama diterangkan oleh Baba dalam bahasa yang berbeda adalah kebenaran yang sama dijelaskan oleh agama para bhakta dalam bahasa buku suci anda. Jika para bhakta menemui kesulitan dengan suatu ide atau persoalna, maka dapat mencari ide atau persoalan serupa yang terdapat dalam pelajaran dan falsafah Sai dan para bhakta boleh meneliti apakah ada suatu jawaban di sana untuk ide atau persoalan yangserupa. Mungkin dengan car aini para bhakta dapat memperoleh jawaban yang para bhakta butuhkan. Dengan cara ini para bhakta dapat memanfaatkan pelajaran dan falsafah Sai. Jangan pernah pindah agama, karena para bhakta merasa, bahwa agama laih belih baik dari pada agama para bhakta yang sekarang. Mungkin bentuk penjelasannya berbeda, sehingga para bhakta memerlukan pendekatna yang berbeda untuk memahaminya, akan tetapi kebenaran yang sama berlaku untuk keduanya. Jika para bhakta sudah menyadari kebenaran ini, maka para bhakta kan menerti, misalnya, bahwa han ya ada satu macam Kasih sayang, yaitu Kasih sayang Universal atau ke-Tuhanan. Semua macam Kasih-sayang lain hanya merupakan bayangan atau pencerminan dari Kasih-sayang ini. Semua perbedaan hanya merupakan perbedaan dari pada interpretasi, bukan perbedaan dari ciri aslinya. 
Semua agama setuju, bahwa Tuhan tidak bernama dan tidak berwujud. Kalau memang demikian, kenapa manusia tertentu mempertahankan, bahwa nama tertentu, yang mereka gunakan untuk Tuhan Yang Tidak Bernama dan Tidak Berwujud, lebih baik dari pada nama yang digunakan orang lain untuk Tuhan Yang Tidak Bernama dan Tidak Berwujud yang sama.

Semua agama mengajarkan bahwa kebenaran, Kebajikan, Kasih sayang, Kedamaian dan Tanpa-kekerasan merupakan sifat-sifat mulia. Jika memang demikian, untuk apa manusia mempermasalahkan, cara manakah yang terbaik untuk memperoleh sifat-sifat ini, jika semua cara ini memberi hasil yang sama. Hargailah pilihan orang lain mengenai kendaraan dan rute perjalannya, itulah jalan Kasih-sayang. Hanya dengan demikian Persatuan dan Kedamaian akan menang dan memerintah. Ini adalah pesan Sai.

\section{e. Konsekuensi-konsekuensi}

Konsekuensi komitmen agama berlainan dari empat dimensi yang sudah diuraian di atas. Dimensi ini mengacu kepada identifikasi akibat-akibat keyakinan keagamaan dalam pendidikan keberagamaan, praktek, pengalaman, dan pengetahuan seseorang bhakta dari hari ke hari. Walaupun agama banyak menggariskan bagaimana pemeluknya seharusnya berfikir dan bertindak dalam kehidupan sehari-hari, tidak sepenuhnya jelas sebatas mana konsekuensikonsekuensi agama merupakan bagian dari komitmen keagamaan atau sematamata berasal dari agama (Glock dan Stark, dalam Imam Suprayogo, 2001: 24).

Harus dicatat pula bahwa ada semacam ketidaksesuaian antara dimensi pengetahuan dan dimensi pengalaman. Lembaga-lembaga keagamaan yang mementingkan suatu dimensi pengetahuan cenderung menganggap kurang penting dimensi yang lain, walaupun dimensi-dimensi tersebut diberi nilai tertentu dalam semua agama (Glock dalam Roland Robertson (Ed) (1995: 31). Namun demikian dalam ajaran Sai bukan hanya menekankan kepada pengguasaan pengetahuan Sai yang berbasis ajaran Weda dan Susastra Hindu, juga menekankan kepada bidang bidang lainnya seperti adanya harapan untuk meningkatkan keyakinan, pengalaman agama dan praktek agama yang berbasis penerapaan Panca Pilar (Satya, Dharma, Ahimsa, Prema dan Santi).

Dengan demikian, dapat diartikan bahwa konsekuensi logis dari keikutsertaan umat sebagai bhakta adalah meyakini beliau sebagai awatar, melaksanakan ajaran beliau secara konsisten, berusaha terus-menerus untuk menghindari segala bentuk larangan, melaksanakan bhajan dan senantiasa menyanyikan kidung suci atau melakukan nama smaranan (menyebut nama Tuhan), dan lain-lain. Selanjutnya, melalui keikutsertaan seseorang untuk menjadi bhakta hendaknya dapat menginternalisasi (menyerap) nilai-nilai ajaran agama yang telah diajarkan sehingga dapat membentuk karakter yang baik. Pembentukan karakter yang baik sebagai wujud terbentuknya kesalehan individual. Sedangkan pembentukan karakter sosial dapat dibangun dari peningkatan aktivitas dalam pelayanan (seva) kepada masyarakat atau lingkungan sosial.

\section{Program Pengembangan Pendidikan Berbasis Pelayanan Sosial di Sai Study Group}

Program Kerja SSG disusun setiap tahun dengan melibatkan seluruh pengurus SSG. Evaluasi terhadap semua kegiatan yang dilakukan selama setahun juga telah dilakukan dengan baik untuk memperbaiki segala kekurangan dan kesalahan yang dilakukan (tanpa evaluasi semua pekerjaan yang telah dilakukan 
menjadi sia-sia). Program kerja SSG meliputi tiga (3) "wings" yaitu pendidikan, pelayanan (tanpa pemerih), dan spiritual. Program bidang pendidikan formal pada saat ini telah beroperasi Sekolah TK Prema Sai Kumara dan SD Satya Sai.

SSG memiliki komitmen kuat dan sangat tinggi terhadap pengembangan pendidikan gratis sebagai wujud pelayanan kepada umat dan sekaligus sebagai upaya untuk meningkatkan kualitas SDM yang berpengetahuan, terampil dan sekaligus bermoral. Sekolah merupakan salah satu lembaga yang bertanggung jawab untuk membentuk orang-orang terpelajar yang dapat diandalkan untuk mengabdi kepada masyarakat dengan penuh kemampuan dan dedikasi. Tanpa penekanan pada pembinaan watak lembaga pendidikan akan menjadi tempat ketidakdisiplinan dan kekacauan.

Mendirikan sebuah Sekolah Dasar yang berlatar belakang hal tersebut di atas merupakan impian dan angan-angan Yayasan Sri Sathya Sai Bali dan Sai Study Group Denpasar sejak dulu. Atas Rahmat Bhagawan Sri Sathya Sai Baba dan kerja keras dari pengurus organisasi serta tidak kalah pentingnya peranan para bakta Sai yang secara bahu membahu dilandasi oleh semangat pengabdian (seva) akhirnya tahun ajaran 2007-2010 Sekolah Dasar Sathya Sai Bali mulai beroperasi (Permadi, 2001: 1). Tujuan berdirinya SD Sathya Sai ini adalah agar siswa dapat menyadari lima dasar Nilai-nilai Kemanusiaan yaitu Kebenaran, Kebajikan, Cinta Kasih, kedamaian, dan Tanpa Kekerasan sebagai bagian penting dari pengembangan karakter dan dapat mengapresiasi rasa persaudaraan di antara umat manusia, serta memelihara kebudayaan adat istiadat serta menghormati kepercayaan orang lain.

Bhagawan Sri Sathya Sai Baba bersabda : perbaikan dalam pendidikan harus dimulai sejak usia Sekolah Dasar ketika watak anak mulai dibina. Bila pendidikan sekarang ini mau diperbaiki maka jalan satu-satunya dengan menghilangkan sifat yang mementingkan diri sendiri dan melatih para pelajar untuk mengabdi kepada masyarakat. Pendidikan menjadi lengkap bila si pelajar bersih sepenuhnya lahir batin. Pendidikan menanamkan kerendahan hati membuat seorang dapat dipercaya sifat itu akan menyebabkan orang tersebut menjadi kaya dan dengan kekayaannya mereka akan dapat beramal untuk kegembiraan serta kedamaian batin (Permadi, 2001: 1).

\section{Kesimpulan}

Pendidikan keberagamaan di kalangan kelompok sepiritual sai study group merupakan sebuah mekanisme belajar dengan menempatkan aspek religius dan aspek pendidikan berjalan beriringan. Pola belajar ditekankan adalah didahului dengan penerapan ajaran agama seperti doa, duduk hening, meditasi, menceritakan kisah-kisah keagamaan, nyangian berkelompok, dan penugasan kelompok. Kegiatan tersebut merupakan tahapan dalam menstimulus peserta didik agar merasa nyaman dan tenang secara psikologis untuk mengikuti pembelajaran di sekolah sai study group. Dengan pola pendidikan tersebut diaktualisasikan oleh peserta didik di sekolah dan dilingkungannya mengarah pada dimensi nilai-nilai kemanusiaan yang terkait pada kebenaran, kebajikan, cinta kasih, kedamaian, dan tanpa kekerasan.

\section{Daftar Pustaka}

Permadi Gd. MPM, 2001 "Sekolah Dasar Sathya Sai Bali:Impian Menuju Kenyataan" dalam Majalah Spiritual Weda Sai Jnana : Love In Action ( Kasih Dalam Tindakan), Vol. 1, Surabaya : Paramita 
Sukadi, 2006, Pendidikan IPS sebagai Rekonstruksi Pengalaman Budaya Berbasis Ideologi Tri Hita Karana (Studi Etnografi Tentang Pengaruh Masyarakat Terhadap Program Pendidikan IPS Pada SMU 1 Ubud Bali, Disertasi Sekolah Pascasarjana Universitas Pendidikan Indoensia BandungPaulo Freire (2002:1213),

Tiong Lie Swan, 2000, Visi dan Misi Ilahi Guru Spiritual Bhagawan Sri Satya Sai Baba, Surabaya, Paramita.

Robertson, Roland (Ed), 1995, Agama dalam Analisa dan Interpretasi Sosiologis, Raja Grafindo Persada : Jakarta.

Jendra, Wayan,2000, "Sekali Lagi tentang Sai Baba " dalam Supartha, Wayan (Ed), 2000, Mengenal Mukjizat Sai Baba di Dalam dan Luar Bali, Denpasar : Penerbit BP.

Suprayoga, Iman dan Tabroni. 2001. Metodologi Penelitian Sosial Agama. Bandung: PT Remaja Rosdakarya. 